\title{
Profound Vitamin D Deficiency in a Diverse Group of Women during Pregnancy Living in a Sun-Rich Environment at Latitude $32^{\circ} \mathbf{N}$
}

\author{
Stuart A. Hamilton, ${ }^{1}$ Rebecca McNeil, ${ }^{2}$ Bruce W. Hollis, ${ }^{3}$ Deborah J. Davis, ${ }^{1}$ Joyce Winkler, ${ }^{1}$ \\ Carolina Cook, ${ }^{1}$ Gloria Warner, ${ }^{1}$ Betty Bivens, ${ }^{3}$ Patrick McShane, ${ }^{1}$ and Carol L. Wagner ${ }^{3}$ \\ ${ }^{1}$ The Eau Claire Study Group, Department of Obstetrics and Gynecology, Eau Claire Cooperative Health Centers, Columbia, \\ SC 29204, USA \\ ${ }^{2}$ Durham Epidemiologic Research and Information Center, Durham Veterans Affairs Medical Center, 508 Fulton Street, \\ Durham, NC 27705, USA \\ ${ }^{3}$ Division of Neonatology, Department of Pediatrics, Medical University of SC, 173 Ashley Avenue, MSC 513, Charleston, \\ SC 29425, USA
}

Correspondence should be addressed to Carol L. Wagner, wagnercl@musc.edu

Received 12 July 2010; Accepted 7 September 2010

Academic Editor: Vin Tangpricha

Copyright (C) 2010 Stuart A. Hamilton et al. This is an open access article distributed under the Creative Commons Attribution License, which permits unrestricted use, distribution, and reproduction in any medium, provided the original work is properly cited.

\begin{abstract}
Objective: Determine prevalence of vitamin D deficiency (VDD) in a diverse group of women presenting for obstetrical care at two community health centers in South Carolina at latitude $32^{\circ} \mathrm{N}$. Methods and Design: Any pregnant woman presenting for care at 2 community health centers was eligible to participate. Sociodemographic and clinical history were recorded. A single blood sample was taken to measure circulating $25(\mathrm{OH}) \mathrm{D}$ as indicator of vitamin D status $[25(\mathrm{OH}) \mathrm{D}<20 \mathrm{ng} / \mathrm{mL}$ ( $50 \mathrm{nmol} / \mathrm{L} \mathrm{deficiency;}$ $<32 \mathrm{ng} / \mathrm{mL}$ ( $80 \mathrm{nmol} / \mathrm{L})$ insufficiency]. Total serum calcium, phosphorus, creatinine, and intact parathyroid hormone also were measured. Results: 559 women, [mean age $25.0 \pm 5.4$ (range 14-43) years] participated: African American (48\%), Hispanic (38\%), Caucasian/Other (14\%). Mean gestational age was $18.5 \pm 8.4$ (median 14.6, range 6.4-39.6) weeks' gestation. $48 \%$ were VDD; an additional 37\% insufficient. Greatest degree was in the African American women (68\% deficient; 94\% insufficient). In multivariable regression, 25(OH)D retained a significant negative association with PTH $(P<.001)$. Conclusions: VDD was high in a diverse group of women, greatest in those of darker pigmentation. The negative correlation between $25(\mathrm{OH}) \mathrm{D}$ and PTH confirms their corroborative use as biomarkers of VDD. These findings raise the issue of adequacy of current vitamin D recommendations for pregnant women.
\end{abstract}

\section{Introduction}

Much has happened in the world of vitamin D research since the 2002 Centers for Disease Control report of the widespread deficiency in African-American women in their childbearing years [1]. Vitamin D is no longer seen as just a "childhood" vitamin that has little bearing on health beyond bone and calcium metabolism [2-4]. Rather, vitamin D is now seen as a preprohormone whose active metabolites act not only to ensure calcium homeostasis and bone health [5] but also act as mediators of immune function in general $[6,7]$, and specific to pregnancy, play a role in immune tolerance, insulin resistance, and preeclampsia [8-12]. Studies to support this premise have increased significantly in number during the past five years [13$30]$, and with frequent lay press articles and featured news items about vitamin $\mathrm{D}$, public understanding of vitamin D's importance in maintaining health has increased. Yet, even with this understanding, the translation of this knowledge into clinical practice in the community is still minimal. Much of the work concerning pregnant women has been performed at university-based clinics, whose relevance to community 
health centers is often in question. Earlier reports of vitamin $\mathrm{D}$ deficiency during pregnancy have focused on women living in northern Europe (latitude $50-55^{\circ} \mathrm{N}$ ), which did not include women of diverse racial/ethnic backgrounds living in a sun-rich environment $[5,31,32]$. Theoretically, women at lower latitudes, despite darker pigmentation, should have less vitamin D deficiency because of the greater likelihood of effective sunlight exposure to induce endogenous vitamin D synthesis [33].

As a result of the concern regarding the prevalence of vitamin $\mathrm{D}$ deficiency among pregnant women receiving care at community health centers, and to clarify earlier scientific studies which reported that a majority of AfricanAmerican and Hispanic women are vitamin D deficient [3440], a cross-sectional study of pregnant women presenting at a community health center network in South Carolina at latitude $32^{\circ} \mathrm{N}$ was designed and implemented. The aim of this study was to define the prevalence of vitamin D deficiency in a large and ethnically diverse cross-sectional sample of pregnant women living in a sun-rich environment with ample access to sunlight during most of the year. It was hypothesized that despite South Carolina's lower latitude and abundance of sunlight, given modern-day lifestyles that often preclude sunlight exposure, the majority of the women presenting for obstetrical care at this community health center network would have vitamin D insufficiency and a significant number would have outright vitamin D deficiency.

\section{Methods and Study Design}

2.1. Subjects. The study was approved by MUSC's Institutional Review Board for Human Research (HR\# 16476) and the Palmetto Baptist Hospital Institutional Review Board for Human Research (PH IRB\# 2007-25). The only inclusion criteria were age of 14 years or more, and confirmed pregnancy at the time of the clinic visit to one of two urban community health networks in Columbia and Charleston, SC. There were no exclusion criteria for participation in the study. This study was conducted from November 21, 2006 through October 31, 2008.

2.2. Procedure. After providing written informed consent, women were asked a series of questions about their sociodemographic characteristics, including self-described race/ethnicity and health status. Sociodemographic and clinical characteristics and obstetrical history were recorded for each woman on a standardized data form. Each woman had been prescribed a prenatal vitamin containing $400 \mathrm{IU}$ of vitamin D at her first prenatal visit; compliance with the prenatal vitamin regimen at the time of the blood sampling was also recorded. A blood sample was drawn with the gestational age (weeks) recorded at the time of the blood sampling. Blood was processed and serum separated for later analysis for total circulating 25-hydroxy-vitamin $\mathrm{D}[25(\mathrm{OH}) \mathrm{D}]$, serum calcium, phosphorus, and creatinine, and intact parathyroid hormone (PTH). Season was calculated from the date that the blood sample was drawn according to the following categories: winter, DecemberMarch; spring, April-May; summer, June-September; fall, October-November.

2.3. Sociodemographic Characteristics of the Cohort. Sociodemographic data were collected on each subject using a standardized data entry form. Specifically, information about maternal age, self-identified ethnicity, health insurance status, marital status, employment status, and educational status was collected. Given the putative relationship between cigarette smoking and PTH [41, 42], information also was collected about cigarette smoking during the current pregnancy.

2.4. Clinical Characteristics of the Cohort. Clinical characteristics included gravidity, parity, and history of preterm birth, preeclampsia, and gestational diabetes during prior pregnancies. Information regarding maternal history of diabetes (type 1 or 2) and chronic hypertension was also recorded. The body mass index (or BMI; $\mathrm{kg} / \mathrm{m}^{2}$ ) was calculated for each woman based on her prepregnancy weight. Women with a prepregnancy BMI equal to or greater than 30 were considered obese.

2.5. Degree of Skin Pigmentation. The degree of skin pigmentation at each of four body sites (forehead, inner underarm, forearm and knee) was recorded using the Smart Probe 400 (IMS, Inc., Milford, CT) and a skin tone chart (IMS, Inc.) on a continuous scale from $0-100$, where absolute black is 0 and absolute white is 100 .

2.6. Measurement of $25(\mathrm{OH}) D$. Total circulating $25(\mathrm{OH}) \mathrm{D}$ concentrations $(\mathrm{ng} / \mathrm{mL})$ were measured using a commercially available radioimmunoassay (RIA) performed in the laboratory of Dr. Bruce Hollis (Diasorin, Stillwater, MN). This laboratory participated throughout the study in the DEQAS quarterly quality control program for vitamin D. A priori, "deficiency" was defined as a concentration $<20 \mathrm{ng} / \mathrm{mL}(<50 \mathrm{nmol} / \mathrm{L})$ and "insufficiency" as a concentration between 20 and $32 \mathrm{ng} / \mathrm{mL}(50-80 \mathrm{nmol} / \mathrm{L})$ [43].

2.7. Measurement of Parathyroid Hormone (PTH). Intact parathyroid hormone $(\mathrm{pg} / \mathrm{mL})$ was measured by a commercially available immunoradiometric assay (N-Tact PTH IRMA; Diasorin, Stillwater, MN) following the manufacturer's guidelines.

2.8. Statistical Analysis. Continuous and ordinal demographic and clinical characteristics were reported as mean \pm SD and median (range). Categorical variables were reported as frequency and percent. Characteristics were tabulated for the entire cohort and according to selfreported race/ethnicity (African-American, Hispanic, Caucasian/Other).

The primary endpoint for this study was total circulating $25(\mathrm{OH}) \mathrm{D}(\mathrm{ng} / \mathrm{mL})$. Secondary endpoints included serum PTH $(\mathrm{pg} / \mathrm{mL})$, calcium $(\mathrm{mg} / \mathrm{dL})$, creatinine $(\mathrm{mg} / \mathrm{dL})$, and phosphorus $(\mathrm{mg} / \mathrm{dL})$. The associations between these 
continuous endpoints and sociodemographic and clinical characteristics were examined using multivariable linear regression, loess regression, and the Kruskal-Wallis test. Participants were categorized as vitamin D deficient, insufficient, or sufficient as described above; the associations between vitamin $\mathrm{D}$ category and predictive factors were evaluated using the chi-square test or Fisher's exact test (categorical predictors) and logistic regression (continuous predictors and/or multivariable models). Results were considered statistically significant for $P$-values less than .05. All analyses were performed using SAS Version 9.1 (SAS Institute Inc., Cary, NC).

\section{Results}

As shown in Table 1, 559 women recruited from two community health center networks in Columbia and Charleston, $\mathrm{SC}$ at latitude $32^{\circ} \mathrm{N}$ participated in the study; 4 participants enrolled twice due to repeated pregnancies during the enrollment period. The mean age was $25.0 \pm 5.4$ (range 14-43) years. The self-reported ethnicities of the participants were African-American (48.1\%), Hispanic (38.1\%), Caucasian (9.5\%) and Other (Asian and American Indian) (4.3\%). No participants younger than age 17 reported having a high school diploma or higher education. The earliest age reported for each category of education was high school, 17 years; some college, 18 years; associate degree or higher, 19 years. Of the participants aged 17 years or greater, $73.3 \%$ reported at least a high school diploma. Of those aged 18 years or greater, $34.8 \%$ reported at least some college. Of those age 19 years or greater, $9.8 \%$ reported achieving an associate's degree or higher $(P<.001$ for association with race/ethnicity). Women in this cohort were more likely to have no insurance $(36.3 \%)$ or Medicaid (44.7\%) than to have private insurance $(P<.001$ for association with race). The majority of the participants (55.1\%) were enrolled during the summer months (June-September).

A total of 252 women (45.1\%) were employed at the time of the study, working a median number of 39 hours worked per week (range 0-84). A total of 88 (15.7\%) reported having stopped their employment due to pregnancy. In addition, 44 $(7.9 \%)$ of the study participants were students at the time of enrollment into the study.

A total of 557 of the 559 participants completed the clinical characteristics survey. For the majority of women in the cohort, pregnancy was unplanned $(64.9 \%, P<.001$ for association with race). The overall median self-rated health status of the women at the time of enrollment was 9 (excellent), and ranged from 3-10 (mean \pm SD, $8.8 \pm 1.2$ ). A total of 190 (34\%) were primigravid women. The median number of prior pregnancies in the cohort was 1 . Of the 367 women with a stated history of a prior pregnancy, 159 (28.4\% total cohort) had 1 prior pregnancy, 97 (17.4\% total cohort) had 2 prior pregnancies, and 111 (19.9\% total cohort) had $\geq 3$ prior pregnancies. Of those women with a history of one or more prior pregnancies, 41 ( $7.3 \%$ total cohort) had a history of preterm birth. In addition, preeclampsia was reported in a prior pregnancy in $21(3.8 \%)$ women, and gestational diabetes was reported in $15(2.7 \%)$ women.
Percent deficiency and insufficiency at baseline by race/ethnicity

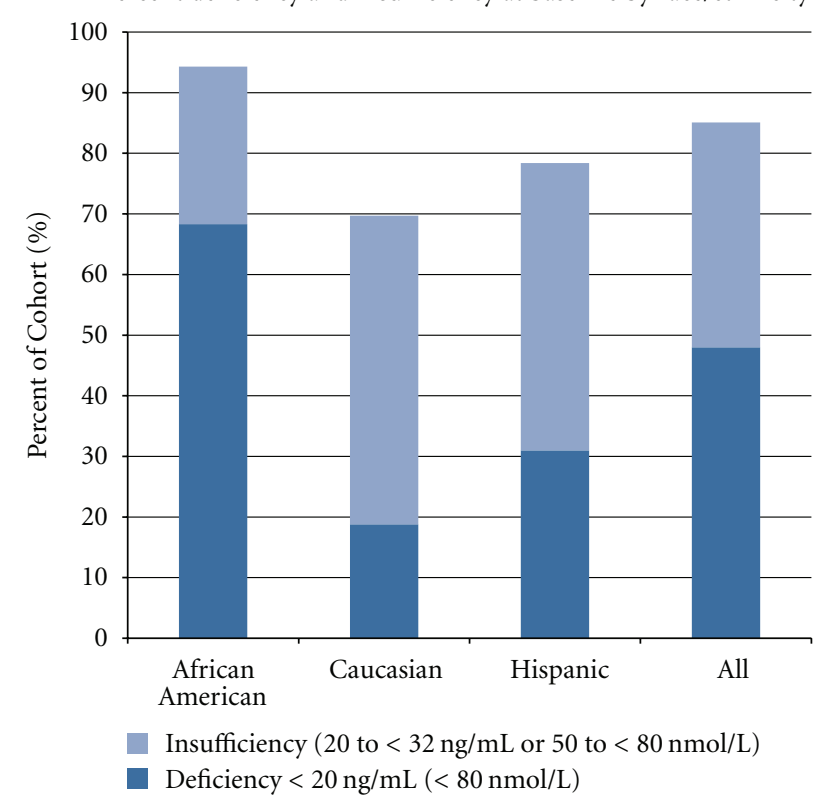

FIGURE 1: Baseline circulating 25(OH)D levels (ng/mL).

A small percentage $(5.2 \%)$ of the women reported dietary restrictions that may have influenced their vitamin D status; $3 \%$ reported such restrictions for health reasons such as type 2 diabetes, $0.9 \%$ for religious reasons (vegetarian), and $1.3 \%$ gave no reason.

The mean vitamin $\mathrm{D}$ status of the cohort, as measured by total circulating $25(\mathrm{OH}) \mathrm{D}$, was $21.7 \pm 9.7 \mathrm{ng} / \mathrm{mL}$ (range 3.8 to 73.8 ; unavailable for 7 participants). Overall, $48 \%$ of the participants were vitamin $D$ deficient, with an additional $37.1 \%$ insufficient. As shown in Figure 1, this varied significantly by self-identified race/ethnicity $(P<.001)$. The greatest degrees of deficiency and insufficiency were seen in the African-American women, with $68.3 \%$ having frank deficiency (concentration $<20 \mathrm{ng} / \mathrm{mL}$ ) and $94.3 \%$ having either deficiency or insufficiency (concentration $<32 \mathrm{ng} / \mathrm{mL}$ ). Table 2 provides additional details regarding the prevalence of the degrees of deficiency by race/ethnicity. In univariate logistic regression models, African-American women had approximately 8 times the odds of vitamin D deficiency of Hispanic women, and 20 times the odds of vitamin $\mathrm{D}$ deficiency of Caucasian women $(P<.001$ for both comparisons). Vitamin D status as measured by $25(\mathrm{OH}) \mathrm{D}$ was also analyzed by season: after controlling for race, there was no significant evidence of seasonal variation in the prevalence of vitamin D insufficiency and/or deficiency in this population.

The mean gestational age was $18.5 \pm 8.4$ (median 14.6, range 6.4-39.6) weeks of gestation (see Table 1). As shown in Table 5, a total of $56.0 \%$ of the cohort were less than 16 weeks of gestation, $24.7 \%$ were between 16 and 28 weeks of gestation, and $17.2 \%$ were at 28 weeks or more of gestation $(0.9 \%$ did not report a gestational age). The odds of vitamin D deficiency (as measured by $25(\mathrm{OH}) \mathrm{D}$ concentration) did not appear to change as a function of 
TABLE 1: Sociodemographic and clinical characteristics at time of enrollment, by self-reported race/ethnicity.

\begin{tabular}{|c|c|c|c|c|c|c|}
\hline $\begin{array}{l}\text { Sociodemographic and clinical } \\
\text { characteristics }\end{array}$ & $\begin{array}{c}\text { Total cohort } \\
N=559\end{array}$ & $\begin{array}{c}\text { African-American } \\
\quad N=269\end{array}$ & $\begin{array}{l}\text { Hispanic } \\
N=213\end{array}$ & $\begin{array}{c}\text { Caucasian } \\
N=53\end{array}$ & $\begin{array}{l}\text { Other ethnicities } \\
\qquad N=24\end{array}$ & $P$-value \\
\hline $\begin{array}{l}\text { Maternal age* } \\
(\text { Mean } \pm \text { SD) }\end{array}$ & $25.0 \pm 5.4$ & $23.9 \pm 5.1$ & $26.1 \pm 5.4$ & $25.8 \pm 5.7$ & $26.8 \pm 5.7$ & $<.001$ \\
\hline $\begin{array}{l}\text { Gestational age* } \\
(\text { Mean } \pm \text { SD }) \\
\end{array}$ & $18.5 \pm 8.4$ & $18.0 \pm 8.0$ & $19.2 \pm 9.0$ & $17.7 \pm 7.8$ & $19.3 \pm 8.2$ & .49 \\
\hline \multicolumn{7}{|l|}{ Highest education achieved } \\
\hline$<$ High school & $155(28 \%)$ & $43(16 \%)$ & $102(48 \%)$ & $8(15 \%)$ & $2(8 \%)$ & \\
\hline High school & $215(38 \%)$ & $100(37 \%)$ & $90(42 \%)$ & $18(34 \%)$ & $7(29 \%)$ & \\
\hline Some college & $138(25 \%)$ & $101(38 \%)$ & $15(7 \%)$ & $16(30 \%)$ & $6(25 \%)$ & $<.001$ \\
\hline Assoc. degree or higher & $51(9 \%)$ & $25(9 \%)$ & $6(3 \%)$ & $11(21 \%)$ & $9(38 \%)$ & \\
\hline Employment (yes) & $252(45 \%)$ & $149(55 \%)$ & $68(32 \%)$ & $28(53 \%)$ & $7(29 \%)$ & $<.001$ \\
\hline \multicolumn{7}{|l|}{ Insurance status } \\
\hline None & $203(36 \%)$ & $4(1 \%)$ & $189(89 \%)$ & $3(6 \%)$ & $7(29 \%)$ & \\
\hline Medicaid & $250(45 \%)$ & $207(77 \%)$ & $12(6 \%)$ & $23(43 \%)$ & $8(33 \%)$ & $<.001$ \\
\hline Private & $106(19 \%)$ & $58(22 \%)$ & $12(6 \%)$ & $27(51 \%)$ & $9(38 \%)$ & \\
\hline \multicolumn{7}{|l|}{ Subjective health rating scale } \\
\hline$(\text { Median, range })^{* *}$ & $\begin{array}{c}9 \\
3-10 \\
\end{array}$ & $\begin{array}{c}9 \\
3-10\end{array}$ & $\begin{array}{c}9 \\
3-10 \\
\end{array}$ & $\begin{array}{c}9 \\
7-10 \\
\end{array}$ & $\begin{array}{c}10 \\
6-10 \\
\end{array}$ & .040 \\
\hline \multicolumn{7}{|l|}{ Prior obstetrical history } \\
\hline Preterm birth & $41(7.3 \%)$ & $27(10.0 \%)$ & $11(5.2 \%)$ & $2(3.8 \%)$ & $1(4.2 \%)$ & .17 \\
\hline Preeclampsia & $21(3.8 \%)$ & $13(4.8 \%)$ & $5(2.4 \%)$ & $2(3.8 \%)$ & $1(4.2 \%)$ & .48 \\
\hline Gestational diabetes & $15(2.7 \%)$ & $9(3.4 \%)$ & $3(1.4 \%)$ & $2(3.8 \%)$ & $1(4.2 \%)$ & .30 \\
\hline Diabetes Mellitus (type 1 or 2 ) & $8(1.4 \%)$ & $6(2.2 \%)$ & $2(0.9 \%)$ & 0 & 0 & .64 \\
\hline Chronic hypertension & $21(3.8 \%)$ & $15(15.6 \%)$ & $1(1.9 \%)$ & $3(1.4 \%)$ & $2(8.3 \%)$ & .036 \\
\hline Planned pregnancy & $196(35 \%)$ & $43(16 \%)$ & $121(57 \%)$ & $21(40 \%)$ & $11(46 \%)$ & $<.001$ \\
\hline Primigravida $^{\dagger}$ & $190(34.1 \%)$ & $98(36.4 \%)$ & $65(30.7 \%)$ & $19(36.5 \%)$ & $8(33.3 \%)$ & .59 \\
\hline $\mathrm{BMI} \geq 30^{\dagger}$ & $174(31.1 \%)$ & $94(34.9 \%)$ & $65(30 \%)$ & $11(21 \%)$ & $4(17 \%)$ & .076 \\
\hline \multicolumn{7}{|l|}{ Season $^{\dagger}$} \\
\hline April-May & $79(14.1 \%)$ & $45(16.7 \%)$ & $23(10.8 \%)$ & $7(13.2 \%)$ & $4(16.7 \%)$ & $<.0001$ \\
\hline June-September & $309(55.3 \%)$ & $127(47.2 \%)$ & $138(64.8 \%)$ & $27(50.9 \%)$ & $17(70.8 \%)$ & \\
\hline October-November & $79(14.1 \%)$ & $32(11.9 \%)$ & $38(17.8 \%)$ & $8(15.1 \%)$ & $1(4.2 \%)$ & \\
\hline December-March & $92(16.5 \%)$ & $65(24.2 \%)$ & $14(6.6 \%)$ & $11(20.8 \%)$ & $2(8.3 \%)$ & \\
\hline
\end{tabular}

$P$-values refer to the comparison between the four racial/ethnic categories reported.

${ }^{*}$ ANOVA; ${ }^{\dagger}$ Chi-square; ${ }^{* *}$ Subjective Health Rating Scale $0=$ poor to $10=$ excellent.

Table 2: Prevalence of vitamin D deficiency ( $N, \%)$ according to race/ethnicity.

\begin{tabular}{|c|c|c|c|c|c|}
\hline Deficiency category & $\begin{array}{l}\text { Total cohort } \\
N=552\end{array}$ & $\begin{array}{l}\text { African-American } \\
\qquad N=262\end{array}$ & $\begin{array}{l}\text { Hispanic } \\
N=213\end{array}$ & $\begin{array}{c}\text { Caucasian } \\
N=53\end{array}$ & $\begin{array}{c}\text { Other Ethnicities } \\
\qquad N=24\end{array}$ \\
\hline$<12 \mathrm{ng} / \mathrm{mL}$ & $87(15.8 \%)$ & $67(25.6 \%)$ & $13(6.1 \%)$ & $4(7.5 \%)$ & $3(12.5 \%)$ \\
\hline $12-19 \mathrm{ng} / \mathrm{mL}$ & $178(32.2 \%)$ & $112(42.7 \%)$ & $53(24.9 \%)$ & $6(11.3 \%)$ & $7(29.2 \%)$ \\
\hline $20-31 \mathrm{ng} / \mathrm{mL}$ & $205(37.1 \%)$ & $68(26.0 \%)$ & $101(47.4 \%)$ & $27(50.9 \%)$ & $10(41.7 \%)$ \\
\hline $32+\mathrm{ng} / \mathrm{mL}$ & $82(14.9 \%)$ & $15(5.7 \%)$ & $46(21.6 \%)$ & $16(30.0 \%)$ & $4(16.7 \%)$ \\
\hline
\end{tabular}

gestational age; women in their later stages of pregnancy had a similar odds of vitamin D deficiency and insufficiency for a given race/ethnicity than women who had their $25(\mathrm{OH}) \mathrm{D}$ concentrations measured earlier in pregnancy $(P=.43)$. A total of $58(10.4 \%)$ participants reported using prenatal vitamins or multivitamins; this was weakly associated with race $(P=.065)$. After controlling for race, prenatal/multivitamin use (containing $400 \mathrm{IU}$ vitamin $\mathrm{D} /$ day) was not associated with $25(\mathrm{OH}) \mathrm{D}$ concentration $(P=.11)$.

We evaluated the use of skin pigmentation score as a surrogate for race; this resulted in a strong correlation between $25(\mathrm{OH}) \mathrm{D}$ concentration and pigmentation score $(P<.002$ for all measurement sites). As expected, this association became nonsignificant when race was added to 
TABLE 3: Multinomial logistic regression model for the univariate associations between vitamin D concentration and age, gravidity, BMI, race, and season of measurement.

\begin{tabular}{|c|c|c|c|c|}
\hline Variable & Vitamin D group & Odds ratio & $95 \% \mathrm{CI}$ & $P$-value \\
\hline \multirow{3}{*}{ Age $<25$} & $<20$ & 1.35 & $0.82-2.21$ & .24 \\
\hline & $20-31$ & 1.28 & $0.77-2.14$ & .35 \\
\hline & $32+$ & $1.00(\mathrm{ref})$ & - & - \\
\hline \multirow{3}{*}{ Primigravida } & $<20$ & 0.82 & $0.49-1.38$ & .45 \\
\hline & $20-31$ & 0.99 & $0.58-1.71$ & .99 \\
\hline & $32+$ & 1.00 (ref) & 一 & 一 \\
\hline \multirow{3}{*}{ Obesity (BMI $\geq 30)$} & $<20$ & 2.19 & $1.23-3.90$ & .008 \\
\hline & $20-31$ & 1.21 & $0.66-2.22$ & .54 \\
\hline & $32+$ & 1.00 (ref) & - & 一 \\
\hline \multirow{3}{*}{ African-American (versus Caucasian) } & $<20$ & 20.28 & $7.91-52.02$ & $<.0001$ \\
\hline & $20-31$ & 2.96 & $1.29-6.78$ & .007 \\
\hline & $32+$ & 1.00 (ref) & - & - \\
\hline \multirow{3}{*}{ Hispanic (versus Caucasian) } & $<20$ & 2.44 & $1.03-5.81$ & .046 \\
\hline & $20-31$ & 1.44 & $0.71-2.90$ & .51 \\
\hline & $32+$ & $1.00(\mathrm{ref})$ & 一 & 一 \\
\hline \multirow{3}{*}{ Summer Months } & $<20$ & 0.60 & $0.34-1.05$ & .073 \\
\hline & $20-31$ & 0.88 & $0.49-1.59$ & .67 \\
\hline & $32+$ & $1.00(\mathrm{ref})$ & - & - \\
\hline
\end{tabular}

Odds ratios are univariate (unadjusted for the other listed covariates); no additional covariates were included in the model. Vitamin D group sample sizes are as follows: $<20, n=265 ; 20-31, n=205 ; 32+, n=82$. Missing data were as follows: gravidity $(n=2)$. The race category of "Other" was excluded from this analysis due to small sample size.

the model. A related measure of sun exposure, derived as the difference in pigmentation scores between the inner underarm and forearm, was not associated with $25(\mathrm{OH}) \mathrm{D}$ concentration $(P=.27)$, as both values changed pursuant to sun exposure.

Multinomial logistic regression models for the three vitamin $\mathrm{D}$ categories (deficient, insufficient, and sufficient) were constructed to evaluate the association between vitamin $\mathrm{D}$ status and age, gravidity, race, and season of measurement. The results of these univariate models are described in Table 3. Specifically, obesity and race demonstrated a significant association with vitamin D category, and obesity retained a significant relationship with vitamin $\mathrm{D}$ category after controlling for race $(P=.01)$.

The association between relevant prior and current medical conditions and present vitamin D status is summarized in Table 4. In exploratory univariate analyses, vitamin D concentrations differed significantly or nearly significantly between subgroups based on hypertension $(P=.055)$, diabetes $(P=.023)$, varicose veins $(P=.056)$, and the presence of any STD $(P<.001)$. After controlling for race, $25(\mathrm{OH}) \mathrm{D}$ concentration differed marginally between subgroups defined by the presence/history of psychiatric illness $(P=.058)$ and diabetes $(P=.074)$. In all of the models described in Table 3, race was a highly significant independent predictor of $25(\mathrm{OH}) \mathrm{D}$ concentration.

Correlation analysis found that $25(\mathrm{OH}) \mathrm{D}$ concentration was weakly, but significantly, associated with serum calcium $(r=0.12, P=.007)$ and negatively associated with PTH $(r=-0.24, P<.001$; see Figure 2$)$ and marginally associated with serum creatinine $(r=-0.08, P=.055)$. Fitting of

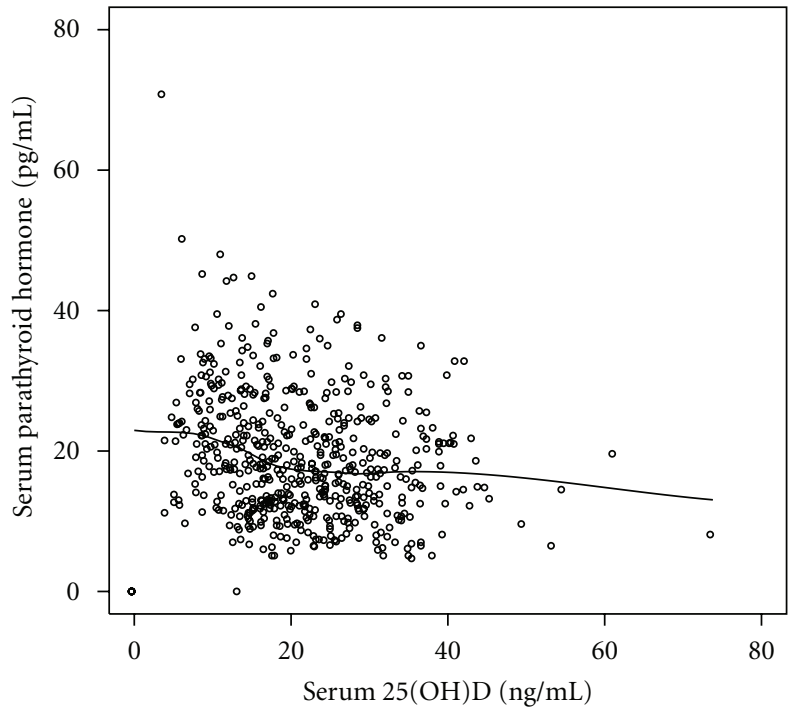

Figure 2: Scatterplot of PTH and 25(OH)D concentrations. The overlaid line modeling the relationship between PTH and $25(\mathrm{OH}) \mathrm{D}$ was fit using loess regression (locally weighted smoothed regression).

a three-parameter exponential decay model suggested that the inflection point at which $25(\mathrm{OH}) \mathrm{D}$ and the effect of higher $25(\mathrm{OH}) \mathrm{D}$ had no further effect on PTH, that is, the relationship reached a plateau was approximately $16.7 \mathrm{ng} / \mathrm{mL}$ (95\% CI $14.8-18.6 \mathrm{ng} / \mathrm{mL})$. There was no evidence of association between $25(\mathrm{OH}) \mathrm{D}$ and serum phosphorus $(r=0.02$, 
TABLE 4: History of prior or current medical conditions of study participants and 25(OH)D concentrations at time of enrollment.

\begin{tabular}{|c|c|c|c|c|}
\hline Medical condition & $N(\%)$ with history & $\begin{array}{c}25(\mathrm{OH}) \mathrm{D} \text { Concentration of } \\
\text { those with history }\end{array}$ & $\begin{array}{l}25(\mathrm{OH}) \mathrm{D} \text { Concentration of } \\
\text { those without history }\end{array}$ & $P$-value \\
\hline Urinary tract infection & $160(28.6 \%)$ & $20.7(8.9)$ & $21.7(10.3)$ & .27 \\
\hline Abnormal PAP smear & $92(16.5 \%)$ & $21.0(11.5)$ & $21.5(9.6)$ & .62 \\
\hline $\begin{array}{l}\text { History of preterm labor or } \\
\text { miscarriage }\end{array}$ & $41(7.3 \%)$ & $18.3(11.2)$ & $21.7(9.8)$ & $.039 *$ \\
\hline Anemia & $47(8.4 \%)$ & $19.5(7.1)$ & $21.6(10.2)$ & .16 \\
\hline Asthma & $45(8.1 \%)$ & $19.6(8.3)$ & $21.6(10.1)$ & .21 \\
\hline Psychiatric illness & $36(6.4 \%)$ & $19.5(8.1)$ & $21.6(10.1)$ & .23 \\
\hline Bipolar disorder & $5(0.9 \%)$ & $23.2(10.2)$ & $21.4(10.0)$ & .68 \\
\hline Depression & $29(5.2 \%)$ & $19.5(8.1)$ & $21.5(10.0)$ & .29 \\
\hline Varicose veins & $23(4.1 \%)$ & $25.3(13.4)$ & $21.3(9.8)$ & .056 \\
\hline Hypertension & $21(3.8 \%)$ & $17.3(10.9)$ & $21.6(9.9)$ & .055 \\
\hline $\begin{array}{l}\text { Kidney stones and/or } \\
\text { disease }\end{array}$ & $10(1.8 \%)$ & $21.7(6.4)$ & $21.4(10.0)$ & .93 \\
\hline Diabetes & $8(1.4 \%)$ & $13.5(4.5)$ & $21.5(10.0)$ & $.023^{*}$ \\
\hline Seizures & $7(1.3 \%)$ & $19.5(8.0)$ & $21.5(10.0)$ & .61 \\
\hline Tuberculosis & $6(1.1 \%)$ & $22.4(5.8)$ & $21.4(10.0)$ & .81 \\
\hline Thyroid disease & $5(0.9 \%)$ & $19.8(11.5)$ & $21.4(10.0)$ & .71 \\
\hline $\begin{array}{l}\text { Any Reported Sexually } \\
\text { Transmitted Disease }\end{array}$ & $126(22.5 \%)$ & $18.3(9.4)$ & $22.3(9.9)$ & $<.001^{*}$ \\
\hline Chlamydia & $99(17.7 \%)$ & $18.2(9.8)$ & $22.1(9.9)$ & $.0003^{*}$ \\
\hline Gonorrhea & $29(5.2 \%)$ & $19.6(7.8)$ & $21.5(10.1)$ & .32 \\
\hline Genital herpes & $11(2.0 \%)$ & $18.1(9.7)$ & $21.5(10.0)$ & .26 \\
\hline Genital warts & $10(1.8 \%)$ & $19.2(5.7)$ & $21.5(10.0)$ & .48 \\
\hline
\end{tabular}

$P=.70)$. Controlling for race did not change the association between $25(\mathrm{OH}) \mathrm{D}$ and calcium. In a multivariable model containing both race and $25(\mathrm{OH}) \mathrm{D}$, race was a significant independent predictor of serum creatinine $(P<.001)$, and the association between creatinine and $25(\mathrm{OH}) \mathrm{D}$ after controlling for race was barely significant $(P=.047)$. Neither race nor $25(\mathrm{OH}) \mathrm{D}$ was associated with serum phosphorus in a multivariable model.

The overall mean \pm SD PTH concentration was 19.2 \pm 8.8 (range 4.7-70.8) pg/mL. As expected, PTH demonstrated a positive association with gestational age category (see Table 5; $P<.001)$. There was no evidence of association between PTH and race $(P=.51$; see Table $6(\mathrm{a}))$. As shown in Table $6(\mathrm{~b})$, in a model of PTH, race did not add significantly to the model $(P=.66)$. Similarly, there was no significant interaction between race and gestational age $(P=.23)$, suggesting that there was no detectable difference between races in the association between PTH and gestational age. These findings suggest that the positive association between PTH and gestational age was consistent among racial/ethnic categories.

After accounting for the effect of gestational age, $25(\mathrm{OH}) \mathrm{D}$ retained a significant negative association with PTH $(P<.001)$. In addition, there was a trend toward increased magnitude of association between $\mathrm{PTH}$ and gestational age among participants with lower $25(\mathrm{OH}) \mathrm{D}(P=.11$ for interaction), suggesting that the increase in PTH due to endogenous production by the placenta is moderated by
$25(\mathrm{OH}) \mathrm{D}$ across the full range of gestational ages. PTH was negatively associated with serum calcium $(r=-0.38, P<$ $.001)$ even after controlling for gestational age, and weakly associated with serum phosphorus $(r=-0.11, P=.011)$; calcium and phosphorus were also associated $(r=0.25$, $P<.001)$.

With regard to cigarette smoking, there were 35 women in the cohort who reported use of cigarettes during the current pregnancy (6.3\%). PTH was significantly associated with reported smoking status (nonsmokers $19.4 \mathrm{pg} / \mathrm{mL}$, smokers $16.6 \mathrm{pg} / \mathrm{mL}, P=.0387)$. The association between PTH and gestational age category, however, was unchanged in effect estimates or significance after controlling for smoking.

\section{Discussion}

Vitamin D deficiency in women of diverse ethnic background, including those of African-American and Hispanic descent, was prevalent in this cohort, more prevalent than what has been reported earlier in women of those ethnicities living at higher latitudes. Overall, $48 \%$ of the participants were vitamin $\mathrm{D}$ deficient, with an additional 37\% being insufficient. This degree of deficiency was noted despite that these women lived in a sun-rich climate for most of the year. Women who reported taking a prenatal vitamin containing 400 IU vitamin D did not differ from those who did not in vitamin $\mathrm{D}$ status as measured by $25(\mathrm{OH}) \mathrm{D}$. 
TABLE 5: Serum 25(OH)D and PTH according to gestational age.

\begin{tabular}{lccc}
\hline & $\begin{array}{c}<156 / 7 \text { weeks } \\
(n=313)\end{array}$ & $\begin{array}{c}16-276 / 7 \text { weeks } \\
(n=138)\end{array}$ & $\begin{array}{c}28+\text { weeks } \\
(n=96)\end{array}$ \\
\hline $\begin{array}{l}\text { 25(OH)D (ng/mL) } \\
\text { Mean } \pm \text { SD }\end{array}$ & $21.9 \pm 9.7$ & $21.2 \pm 9.1$ & $22.2 \pm 10.7$ \\
$\begin{array}{l}\text { Median (range) } \\
\text { PTH (pg/mL) }\end{array}$ & $20.5(4.2-73.8)$ & $20.4(5.1-44.1)$ & $20.4(3.8-61.3)$ \\
Mean \pm SD & $16.9 \pm 7.2$ & $21.3 \pm 9.0$ & $23.9 \pm 10.6$ \\
Median (range) & $15.7(4.7-39.5)$ & $20.2(5.8-48.0)$ & $22.4(6.6-70.8)$ \\
\hline
\end{tabular}

Reported as mean (SD) in row 1 , and median (range) in row $2 .{ }^{*}$ Missing data $(n=1)$ for PTH.

TABLE 6: Intact PTH during pregnancy by race/ethnicity and gestational age at time of measurement.

(a) Estimated PTH $(\mathrm{pg} / \mathrm{mL})$ levels for each category of self-identified race and ethnicity ${ }^{\dagger}$

\begin{tabular}{lccr}
\hline & $N^{*}$ & Mean (SD) & Range \\
\hline All participants & 551 & $19.2(8.8)$ & $4.7-70.8$ \\
African-American & 261 & $19.6(9.5)$ & $5.1-70.8$ \\
Caucasian & 53 & $17.9(9.1)$ & $6.2-38.7$ \\
Hispanic & 213 & $19.1(8.0)$ & $4.7-40.9$ \\
Other & 24 & $18.0(6.6)$ & $7.6-32.6$ \\
\hline
\end{tabular}

${ }^{\dagger}$ Eight subjects had insufficient blood sample to measure PTH and thus, were excluded from this table.

(b) Serum PTH (pg/mL) according to gestational age and race/ethnicity**

\begin{tabular}{|c|c|c|c|}
\hline & \multicolumn{3}{|c|}{ PTH According to Gestational Age and Race/Ethnicity } \\
\hline & $\begin{array}{l}<32 \text { weeks } \\
(n=484)\end{array}$ & $\begin{array}{c}32-35 \text { weeks } \\
\quad(n=36)\end{array}$ & $\begin{array}{c}36+\text { weeks } \\
(n=26)\end{array}$ \\
\hline All participants & $\begin{array}{c}18.7(8.5) \\
17.4(4.7-70.8)\end{array}$ & $\begin{array}{c}21.5(9.1) \\
22.1(6.6-44.2)\end{array}$ & $\begin{array}{c}26.9(9.6) \\
27.9(9.6-45.2)\end{array}$ \\
\hline African-American & $\begin{array}{c}19.0(9.0) \\
17.3(5.1-70.8)\end{array}$ & $\begin{array}{c}22.0(10.9) \\
22.8(6.6-44.2)\end{array}$ & $\begin{array}{c}32.9(9.8) \\
33.2(17.2-45.2)\end{array}$ \\
\hline Caucasian & $\begin{array}{c}17.6(8.8) \\
15.3(6.4-38.7)\end{array}$ & $\begin{array}{c}20.3(9.5) \\
21.7(10.2-29.1)\end{array}$ & $\begin{array}{c}27.8(-) \\
27.8(18.2-37.3)\end{array}$ \\
\hline Hispanic & $\begin{array}{c}18.5(8.0) \\
17.7(4.7-40.9)\end{array}$ & $\begin{array}{c}22.6(7.0) \\
24.2(7.0-30.8)\end{array}$ & $\begin{array}{c}23.1(7.5) \\
21.8(9.6-33.6)\end{array}$ \\
\hline Other & $\begin{array}{c}18.5(6.5) \\
16.9(10.7-32.6)\end{array}$ & $\begin{array}{c}11.8(-) \\
11.8(7.6-16.0)\end{array}$ & \\
\hline
\end{tabular}

** Reported as mean (SD) in row 1 and median (range) in row 2. Blank cells are those that contain no participants. SD was not estimated in cells that contain fewer than 3 observations.

While present in Caucasian women, the greatest prevalence of deficiency was noted in those women of darker pigmentation, specifically, African-American and Hispanic women. While there was a significant variation in $25(\mathrm{OH}) \mathrm{D}$ concentrations between racial/ethnic categories, the deficiency did not appear to change as a function of gestational age; women in their later stages of pregnancy had a similar risk of vitamin D deficiency and insufficiency for a given race/ethnicity compared with women who had their $25(\mathrm{OH}) \mathrm{D}$ concentrations measured earlier in pregnancy. This suggests that any reductions in sun exposure attributable to the limited mobility or lower maternal body self-image experienced during later stages of pregnancy did not have a meaningful impact on $25(\mathrm{OH}) \mathrm{D}$ concentrations. While we lack specific sun exposure data, we hypothesize that this apparent absence of association may be due to minimal sun exposure among our participants at all gestational ages, as reflected by their low $25(\mathrm{OH}) \mathrm{D}$ status.

Prior studies have reported conflicting data about PTH concentrations during pregnancy. Some investigators reported that PTH bioactivity during pregnancy is either in the normal range [44-47] or increases [48-52]; while others have reported that intact PTH concentration is approximately half that seen in the nonpregnant woman $[53,54]$. Okonofua et al. [55], in response to these differences in study findings, designed a study to elucidate PTH activity during pregnancy. In their study of Asian and Caucasian women in the UK, PTH concentrations were greater in Asian than Caucasian women, but despite these differences, both groups maintained blood calcium concentrations in the normal range. When both groups were combined, PTH was inversely related to both plasma 
calcium and $25(\mathrm{OH}) \mathrm{D}$. In contrast, when the groups were analyzed separately, the inverse correlation between PTH and calcium persisted whereas the relationship between PTH and 25(OH)D disappeared. This observation was the first of its kind in the literature. The authors suggested that this significant inverse relationship between calcium and PTH concentrations in a group of women whose calcium concentrations were within the normal range was consistent with the premise that PTH secretion is responsive to alternations in calcium concentration during pregnancy irrespective of the underlying trends toward an increase in PTH during pregnancy.

In our study, while PTH demonstrated a positive association with gestational age, there was no evidence of an interaction between gestational age and race, which suggests that the positive association between PTH and gestational age was consistent among racial/ethnic categories. After accounting for the effect of gestational age through multivariable regression, $25(\mathrm{OH}) \mathrm{D}$ status retained a significant negative association with $\mathrm{PTH}$, confirming that even during pregnancy, PTH is a predictor of vitamin D deficiency. Our results regarding the association between $\mathrm{PTH}$ and calcium were consistent with those of Okonofua et al. [55], from two decades ago with a population of women of diverse ethnicity.

Using both circulating $25(\mathrm{OH}) \mathrm{D}$ and PTH as markers of vitamin $\mathrm{D}$ deficiency, these findings underscore recent reports of widespread vitamin D deficiency among pregnant women, even in areas of the world with ample sunlight. This is concerning in that the effects of vitamin D deficiency among pregnancy women are not limited to the women: if a mother has vitamin D insufficiency, or worse, deficiency, her fetus is developing in a hypovitaminotic state. At its most basic concentration, such a burden of deficiency sets the stage of subsequent deficiency for the neonate and infant whose stores of vitamin D were set during pregnancy. Infants who are vitamin D deficient at birth are at the highest risk of impaired bone development [5] that appears to persist in even later childhood [37]. What is most concerning is that use of prenatal vitamins containing $400 \mathrm{IU} /$ tablet was irrelevant in affecting vitamin D status: those who took their prescribed prenatal vitamin containing vitamin $\mathrm{D}$ did not differ from those who did not. Women taking their prenatal vitamins should be counseled that the amount of vitamin D contained in their prenatal vitamin will not affect their vitamin D status [33, 56, 57].

The strengths of the study are that a large and diverse group of women at various stages of pregnancy were studied to: (1) ascertain their vitamin D status at the time of presentation to a community health center and (2) find what factors were most predictive of that status in a sun-rich environment where theoretically there are no limitations to achieving an adequate vitamin D status. Potential limitations of this study include that the active form of vitamin D, $1,25(\mathrm{OH})_{2} \mathrm{D}$, was not measured. In addition, while maternal use of prenatal vitamins was recorded, compliance with this regimen was not ascertained through pill counts. We have established previously that pill counts are not necessarily predictive of adherence to protocol and only biochemical measures give one a true indication of adherence [58].
Given recent discoveries that link vitamin $\mathrm{D}$ with the innate immune system [6], it is not unreasonable to predict that deficiencies during fetal development could have lasting sequelae on the child, not only in terms of bone mineralization, but also in terms of immune development that becomes the basis for later derangements seen with long-latency diseases such as multiple sclerosis, rheumatoid arthritis, diabetes, and certain cancers [59]. However, little is currently known about the long-term sequelae of fetal hypovitaminosis D on immune function. Studies to examine the benefit of higher doses of vitamin $\mathrm{D}$ during pregnancy suggest that the dose of vitamin $\mathrm{D}$ found in most prenatal vitamins - $400 \mathrm{IU}$ - is inadequate to meet the needs of the pregnant woman and her growing fetus $[11,32,34,39$, 60-67]. Taking into account vitamin D's emerging role in immune maintenance throughout the body and the mounting evidence to support the importance of vitamin D in maintaining good health, at the very least, women who are deficient in vitamin $\mathrm{D}$ should be counseled regarding the risks of vitamin $\mathrm{D}$ deficiency for themselves and their offspring and recommended a therapy to ensure vitamin D adequacy $[60-62,68-70]$.

\section{Acknowledgments}

The authors gratefully acknowledge the strong guidance and mentorship provided by Robert F. Woolson, Ph.D., during the design and implementation of this study. The authors also would like to acknowledge the scientific assistance of Dr. Connie Weaver during data analysis and in the writing of this manuscript. This study was funded by the Thrasher Research Fund, GCRC/CTRC NIH RR01070, and the Division of Neonatology, Medical University of South Carolina, Charleston, SC. R. McNeil's contributions to this research were performed while she was a research associate at the Biostatistics Unit, Mayo Clinic Florida, 4500 San Pablo Road, Jacksonville, FL 32224.

\section{References}

[1] S. Nesby-O'Dell, K. S. Scanlon, M. E. Cogswell et al., "Hypovitaminosis D prevalence and determinants among African American and white women of reproductive age: third National Health and Nutrition Examination Survey, 19881994," American Journal of Clinical Nutrition, vol. 76, no. 1, pp. 187-192, 2002.

[2] C. L. Wagner and F. R. Greer, "Prevention of rickets and vitamin D deficiency in infants, children, and adolescents," Pediatrics, vol. 122, no. 5, pp. 1142-1152, 2008.

[3] C. L. Wagner, S. N. Taylor, and B. W. Hollis, "Does vitamin D make the world go 'round'?" Breastfeeding Medicine, vol. 3, no. 4, pp. 239-250, 2008.

[4] B. W. Hollis, "US recommendations fail to correct vitamin D deficiency," Nature Reviews Endocrinology, vol. 5, no. 10, pp. 534-536, 2009.

[5] P. Mahon, N. Harvey, S. Crozier et al., "Low maternal vitamin D status and fetal bone development: cohort study," Journal of Bone and Mineral Research, vol. 25, no. 1, pp. 14-19, 2010.

[6] P. T. Liu, S. Stenger, H. Li et al., "Toll-like receptor triggering of a vitamin D-mediated human antimicrobial response," Science, vol. 311, no. 5768, pp. 1770-1773, 2006. 
[7] P. T. Liu, S. Stenger, D. H. Tang, and R. L. Modlin, "Cutting edge: vitamin D-mediated human antimicrobial activity against Mycobacterium tuberculosis is dependent on the induction of cathelicidin," Journal of Immunology, vol. 179, no. 4, pp. 2060-2063, 2007.

[8] L. M. Bodnar, J. M. Catov, H. N. Simhan, M. F. Holick, R. W. Powers, and J. M. Roberts, "Maternal vitamin D deficiency increases the risk of preeclampsia," Journal of Clinical Endocrinology and Metabolism, vol. 92, no. 9, pp. 3517-3522, 2007.

[9] E. Hyppönen, "Vitamin D for the prevention of preeclampsia? A hypothesis," Nutrition Reviews, vol. 63, no. 7, pp. 225-232, 2005.

[10] C. J. Robinson, M. C. Alanis, C. L. Wagner, B. W. Hollis, and D. D. Johnson, "Plasma 25-hydroxyvitamin D levels in earlyonset severe preeclampsia," American Journal of Obstetrics and Gynecology, vol. 203, no. 4, pp. 361-366, 2010.

[11] E. Hyppönen and B. J. Boucher, "Avoidance of vitamin D deficiency in pregnancy in the United Kingdom: the case for a unified approach in National policy," British Journal of Nutrition, vol. 104, no. 3, pp. 309-314, 2010.

[12] Z. Maghbooli, A. Hossein-Nezhad, F. Karimi, A.-R. Shafaei, and B. Larijani, "Correlation between vitamin $\mathrm{D}_{3}$ deficiency and insulin resistance in pregnancy," Diabetes/Metabolism Research and Reviews, vol. 24, no. 1, pp. 27-32, 2008.

[13] E. Y. Enioutina, D. Bareyan, and R. A. Daynes, "TLR-induced local metabolism of vitamin $\mathrm{D}_{3}$ plays an important role in the diversification of adaptive immune responses," Journal of Immunology, vol. 182, no. 7, pp. 4296-4305, 2009.

[14] J. S. Adams, S. Ren, P. T. Liu et al., "Vitamin d-directed rheostatic regulation of monocyte antibacterial responses," Journal of Immunology, vol. 182, no. 7, pp. 4289-4295, 2009.

[15] J. Tang, R. Zhou, D. Luger et al., "Calcitriol suppresses antiretinal autoimmunity through inhibitory effects on the Th17 effector response," Journal of Immunology, vol. 182, no. 8, pp. 4624-4632, 2009.

[16] C. M. Fronczak, A. E. Barón, H. P. Chase et al., "In utero dietary exposures and risk of islet autoimmunity in children," Diabetes Care, vol. 26, no. 12, pp. 3237-3242, 2003.

[17] M. T. Cantorna, Y. Zhu, M. Froicu, and A. Wittke, "Vitamin D status, 1,25-dihydroxyvitamin $\mathrm{D}_{3}$, and the immune system," The American Journal of Clinical Nutrition, vol. 80, no. 6, pp. 1717S-1720S, 2004.

[18] M. T. Cantorna and B. D. Mahon, "Mounting evidence for vitamin $\mathrm{D}$ as an environmental factor affecting autoimmune disease prevalence," Experimental Biology and Medicine, vol. 229, no. 11, pp. 1136-1142, 2004.

[19] J. J. Cannell, R. Vieth, J. C. Umhau et al., "Epidemic influenza and vitamin D," Epidemiology and Infection, vol. 134, no. 6, pp. 1129-1140, 2006.

[20] E. Ginanjar, Sumariyono, S. Setiati, and B. Setiyohadi, "Vitamin D and autoimmune disease," Acta Medica Indonesiana, vol. 39, no. 3, pp. 133-141, 2007.

[21] S. Chen, G. P. Sims, X. X. Chen, Y. Y. Gu, S. Chen, and P. E. Lipsky, "Modulatory effects of 1,25-dihydroxyvitamin $\mathrm{D}_{3}$ on human B cell differentiation," Journal of Immunology, vol. 179, no. 3, pp. 1634-1647, 2007.

[22] J. Schauber, R. A. Dorschner, A. B. Coda et al., "Injury enhances TLR2 function and antimicrobial peptide expression through a vitamin D-dependent mechanism," Journal of Clinical Investigation, vol. 117, no. 3, pp. 803-811, 2007.

[23] Y. Arnson, H. Amital, and Y. Shoenfeld, "Vitamin D and autoimmunity: new aetiological and therapeutic considerations," Annals of the Rheumatic Diseases, vol. 66, no. 9, pp. 1137-1142, 2007.
[24] I. Laaksi, J.-P. Ruohola, P. Tuohimaa et al., "An association of serum vitamin $\mathrm{D}$ concentrations $<40 \mathrm{nmol} / \mathrm{L}$ with acute respiratory tract infection in young Finnish men," American Journal of Clinical Nutrition, vol. 86, no. 3, pp. 714-717, 2007.

[25] Y. Arnson, H. Amital, and Y. Shoenfeld, "Vitamin D and autoimmunity: new aetiological and therapeutic considerations," Annals of the Rheumatic Diseases, vol. 66, no. 9, pp. 1137-1142, 2007.

[26] S. Byers and S. Shah, "Vitamin D and the regulation of Wnt/beta-catenin signaling and innate immunity in colorectal cancer," Nutrition Reviews, vol. 65, no. 8, pp. S118-S120, 2007.

[27] I. Laaksi, J.-P. Ruohola, P. Tuohimaa et al., "An association of serum vitamin $\mathrm{D}$ concentrations $<40 \mathrm{nmol} / \mathrm{L}$ with acute respiratory tract infection in young Finnish men," American Journal of Clinical Nutrition, vol. 86, no. 3, pp. 714-717, 2007.

[28] A. R. Martineau, R. J. Wilkinson, K. A. Wilkinson et al., "A single dose of vitamin D enhances immunity to mycobacteria," American Journal of Respiratory and Critical Care Medicine, vol. 176, no. 2, pp. 208-213, 2007.

[29] M. Cutolo and K. Otsa, "Vitamin D, immunity and lupus," Lupus, vol. 17, no. 1, pp. 6-10, 2008.

[30] D. Kamen and C. Aranow, "Vitamin D in systemic lupus erythematosus," Current Opinion in Rheumatology, vol. 20, no. 5, pp. 532-537, 2008.

[31] V. A. Holmes, M. S. Barnes, H. D. Alexander, P. McFaul, and J. M. Wallace, "Vitamin D deficiency and insufficiency in pregnant women: a longitudinal study," The British Journal of Nutrition, vol. 102, no. 6, pp. 876-881, 2009.

[32] C. K. H. Yu, L. Sykes, M. Sethi, T. G. Teoh, and S. Robinson, "Vitamin D deficiency and supplementation during pregnancy," Clinical Endocrinology, vol. 70, no. 5, pp. 685-690, 2009.

[33] B. W. Hollis and C. L. Wagner, "Assessment of dietary vitamin $\mathrm{D}$ requirements during pregnancy and lactation," American Journal of Clinical Nutrition, vol. 79, no. 5, pp. 717-726, 2004.

[34] E. E. Delvin, B. L. Salle, and F. H. Glorieux, "Vitamin D supplementation during pregnancy: effect on neonatal calcium homeostasis," Journal of Pediatrics, vol. 109, no. 2, pp. 328-334, 1986.

[35] T. Markestad, L. Aksnes, M. Ulstein, and D. Aarskog, "25Hydroxyvitamin D and 1,25-dihydroxyvitamin D of D2 and $\mathrm{D}_{3}$ origin in maternal and umbilical cord serum after vitamin D2 supplementation in human pregnancy," American Journal of Clinical Nutrition, vol. 40, no. 5, pp. 1057-1063, 1984.

[36] E. Mallet, B. Gugi, P. Brunelle, A. Henocq, J. P. Basuyau, and H. Lemeur, "Vitamin D supplementation in pregnancy: a controlled trial of two methods," Obstetrics \& Gynecology, vol. 68, pp. 300-304, 1986.

[37] M. K. Javaid, S. R. Crozier, N. C. Harvey et al., "Maternal vitamin D status during pregnancy and childhood bone mass at age 9 years: a longitudinal study," Lancet, vol. 367, no. 9504, pp. 36-43, 2006.

[38] O. G. Brooke, I. R.F. Brown, and C. D.M. Bone, "Vitamin D supplements in pregnant Asian women: effects on calcium status and fetal growth," British Medical Journal, vol. 280, no. 6216, pp. 751-754, 1980.

[39] J. D. Maxwell, L. Ang, O. G. Brooke, and I. R. F. Brown, "Vitamin D supplements enhance weight gain and nutritional status in pregnant Asians," British Journal of Obstetrics and Gynaecology, vol. 88, no. 10, pp. 987-991, 1981.

[40] M. Alfaham, S. Woodhead, G. Pask, and D. Davies, "Vitamin D deficiency: a concern in pregnant Asian women," British Journal of Nutrition, vol. 73, no. 6, pp. 881-887, 1995. 
[41] M. Sneve, N. Emaus, R. M. Joakimsen, and R. Jorde, "The association between serum parathyroid hormone and bone mineral density, and the impact of smoking: the Troms $\varnothing$ Study," European Journal of Endocrinology, vol. 158, no. 3, pp. 401-409, 2008.

[42] D. Kapoor and T. H. Jones, "Smoking and hormones in health and endocrine disorders," European Journal of Endocrinology, vol. 152, no. 4, pp. 491-499, 2005.

[43] B. W. Hollis, "Circulating 25-hydroxyvitamin D levels indicative of vitamin D sufficiency: implications for establishing a new effective dietary intake recommendation for vitamin D," Journal of Nutrition, vol. 135, no. 2, pp. 317-322, 2005.

[44] J. J. Steichen, R. C. Tsang, and T. L. Gratton, "Vitamin D homeostasis in the perinatal period. 1,25-dihydroxyvitamin D in maternal, cord, and neonatal blood," New England Journal of Medicine, vol. 302, no. 6, pp. 315-319, 1980.

[45] J. C. Stevenson, M. I. Whitehead, and G. Lane, "Calcium homoeostasis during pregnancy," British Medical Journal (Clinical Research ed.), vol. 283, no. 6295, pp. 860-861, 1981.

[46] M. Whitehead, G. Lane, and O. Young, "Interrelations of calcium-regulating hormones during normal pregnancy," British Medical Journal, vol. 283, no. 6283, pp. 10-12, 1981.

[47] M. E. Gillette, K. L. Insogna, A. M. Lewis, and D. T. Baran, "Influence of pregnancy on immunoreactive parathyroid hormone levels," Calcified Tissue International, vol. 34, no. 1, pp. 9-12, 1982.

[48] R. M. Pitkin and M. P. Gebhardt, "Serum calcium concentrations in human pregnancy," American Journal of Obstetrics and Gynecology, vol. 127, no. 7, pp. 775-778, 1977.

[49] R. M. Pitkin, "Calcium metabolism in pregnancy and the perinatal period: a review," American Journal of Obstetrics and Gynecology, vol. 151, no. 1, pp. 99-109, 1985.

[50] R. M. Pitkin, W. A. Reynolds, G. A. Williams, and G. K. Hargis, "Calcium metabolism in normal pregnancy: a longitudinal study," American Journal of Obstetrics and Gynecology, vol. 133, no. 7, pp. 781-790, 1979.

[51] W. G. Cushard Jr., M. A. Creditor, J. M. Canterbury, and E. Reiss, "Physiologic hyperparathyroidism in pregnancy," Journal of Clinical Endocrinology and Metabolism, vol. 34, no. 5, pp. 767-771, 1972.

[52] C. E. Dent and M. M. Gupta, "Plasma 25 hydroxyvitamin D levels during pregnancy in Caucasians and in vegetarian and non vegetarian Asians," Lancet, vol. 2, no. 7944, pp. 10571060, 1975.

[53] J. Allgrove, S. Adami, R. M. Manning, and J. L. H. O’Riordan, "Cytochemical bioassay of parathyroid hormone in maternal and cord blood," Archives of Disease in Childhood, vol. 60, no. 2, pp. 110-115, 1985.

[54] S. Bertelloni, G. I. Baroncelli, A. Pelletti, R. Battini, and G. Saggese, "Parathyroid hormone-related protein in healthy pregnant women," Calcified Tissue International, vol. 54, no. 3, pp. 195-197, 1994.

[55] F. Okonofua, R. K. Menon, and S. Houlder, "Calcium, vitamin D and parathyroid hormone relationships in pregnant Caucasian and Asian women and their neonates," Annals of Clinical Biochemistry, vol. 24, no. 1, pp. 22-28, 1987.

[56] B. W. Hollis, "Vitamin D requirement during pregnancy and lactation," Journal of Bone and Mineral Research, vol. 22, no. 2, pp. V39-V44, 2007.

[57] C. Wagner, S. Taylor, and B. Hollis, New Insights into Vitamin D during Pregnancy, Lactation and Early Infancy, Hale Publishers, Amarillo, Tex, USA, 1st edition, 2010.
[58] K. E. Appelgren, P. J. Nietert, T. C. Hulsey, B. W. Hollis, and C. L. Wagner, "Analyzing adherence to prenatal supplement: does pill count measure up?" International Journal of Endocrinology, vol. 2010, Article ID 631971, 8 pages, 2010.

[59] J. McGrath, "Does 'imprinting' with low prenatal vitamin D contribute to the risk of various adult disorders?" Medical Hypotheses, vol. 56, no. 3, pp. 367-371, 2001.

[60] C. L. Wagner, D. Johnson, T. Hulsey et al., "Vitamin D supplementation during pregnancy part I NICHD/CTSA randomized clinical trial (RCT): safety considerations," in Pediatric Academic Societies Annual Meeting, Vancouver, Canada, May 2010, abstract 2630.7.

[61] C. Wagner, D. Johnson, T. Hulsey et al., "Vitamin D supplementation during pregnancy part 2 NICHD/CTSA randomized clinical trial (RCT): outcomes," Pediatric Academic Societies Annual Meeting, Vancouver, Canada, May 2010, abstract 1665.6.

[62] C. L. Wagner, R. McNeil, S. A. Hamilton et al., "Vitamin D (vitD) supplementation during pregnancy: Thrasher Research Fund RCT in SC Community Health Center Networks," Pediatric Academic Societies Annual Meeting, Vancouver, Canada, May 2010, abstract 3737.375.

[63] F. Cockburn, N. R. Belton, and R. J. Purvis, "Maternal vitamin $\mathrm{D}$ intake and mineral metabolism in mothers and their newborn infants," British Medical Journal, vol. 281, no. 6232, pp. 11-14, 1980.

[64] R. J. Purvis, G. S. MacKay, and W. J.M. Barrie, "Enamel hypoplasia of the teeth associated with neonatal tetany: a manifestation of maternal vitamin D deficiency," Lancet, vol. 2, no. 7833, pp. 811-814, 1973.

[65] O. G. Brooke, I. R.F. Brown, and C. D.M. Bone, "Vitamin D supplements in pregnant Asian women: effects on calcium status and fetal growth," British Medical Journal, vol. 280, no. 6216, pp. 751-754, 1980 .

[66] O. G. Brooke, F. Butters, and C. Wood, "Intrauterine vitamin D nutrition and postnatal growth in Asian infants," British Medical Journal, vol. 283, no. 6298, p. 1024, 1981.

[67] O. G. Brooke, I. R. F. Brown, and H. J. W. Cleeve, “Observations on the vitamin $\mathrm{D}$ state of pregnant Asian women in London," British Journal of Obstetrics and Gynaecology, vol. 88, no. 1, pp. 18-26, 1981.

[68] B. W. Hollis and C. L. Wagner, "Assessment of dietary vitamin $\mathrm{D}$ requirements during pregnancy and lactation," American Journal of Clinical Nutrition, vol. 79, no. 5, pp. 717-726, 2004.

[69] B. W. Hollis, "Circulating 25-hydroxyvitamin D levels indicative of vitamin D sufficiency: implications for establishing a new effective dietary intake recommendation for vitamin D," Journal of Nutrition, vol. 135, no. 2, pp. 317-322, 2005.

[70] R. Vieth, H. Bischoff-Ferrari, B. J. Boucher et al., "The urgent need to recommend an intake of vitamin D that is effective," American Journal of Clinical Nutrition, vol. 85, no. 3, pp. 649650, 2007. 


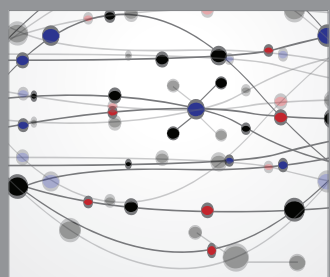

The Scientific World Journal
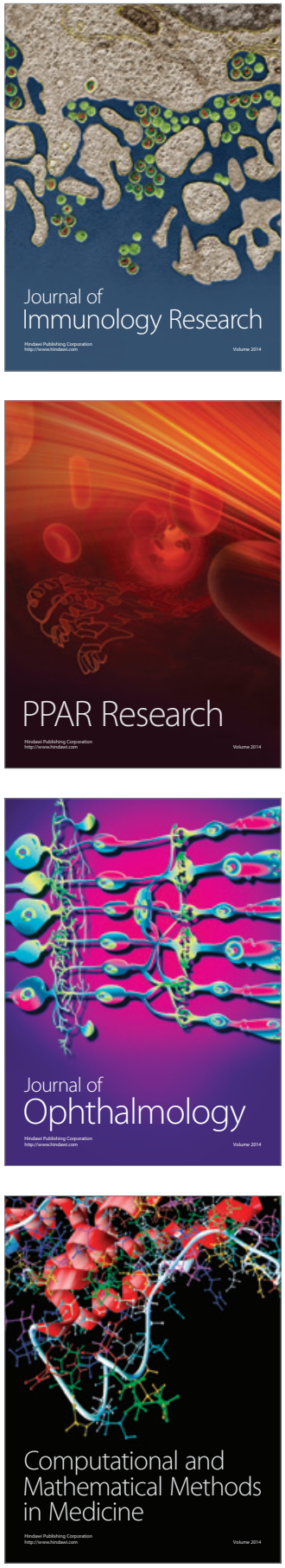

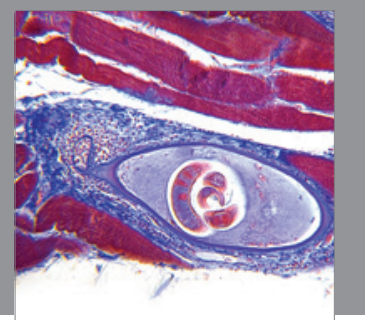

Gastroenterology

Research and Practice
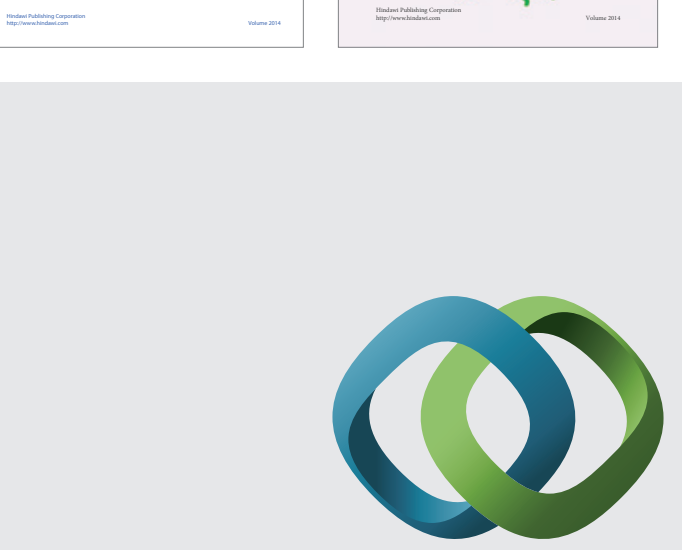

\section{Hindawi}

Submit your manuscripts at

http://www.hindawi.com
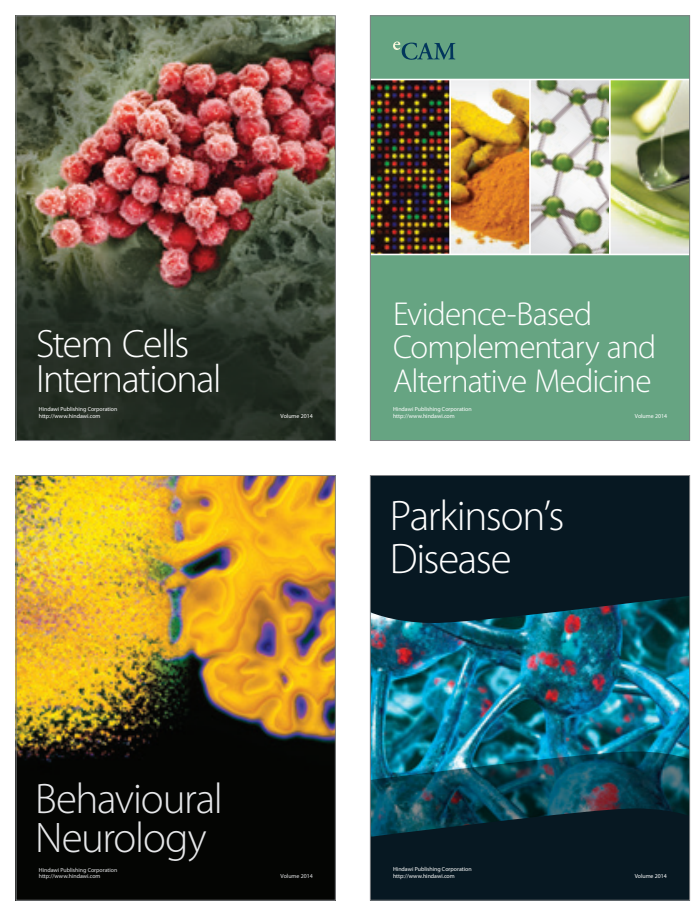

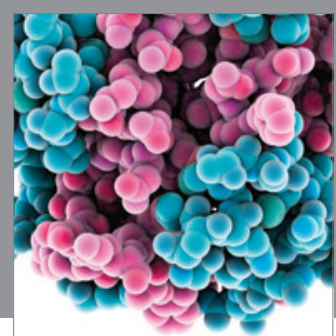

Journal of
Diabetes Research

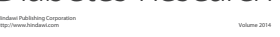

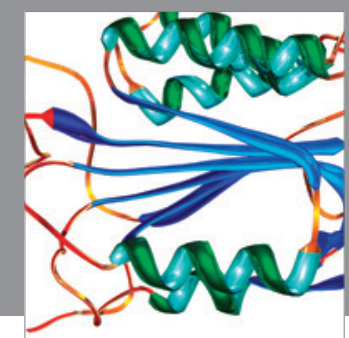

Disease Markers
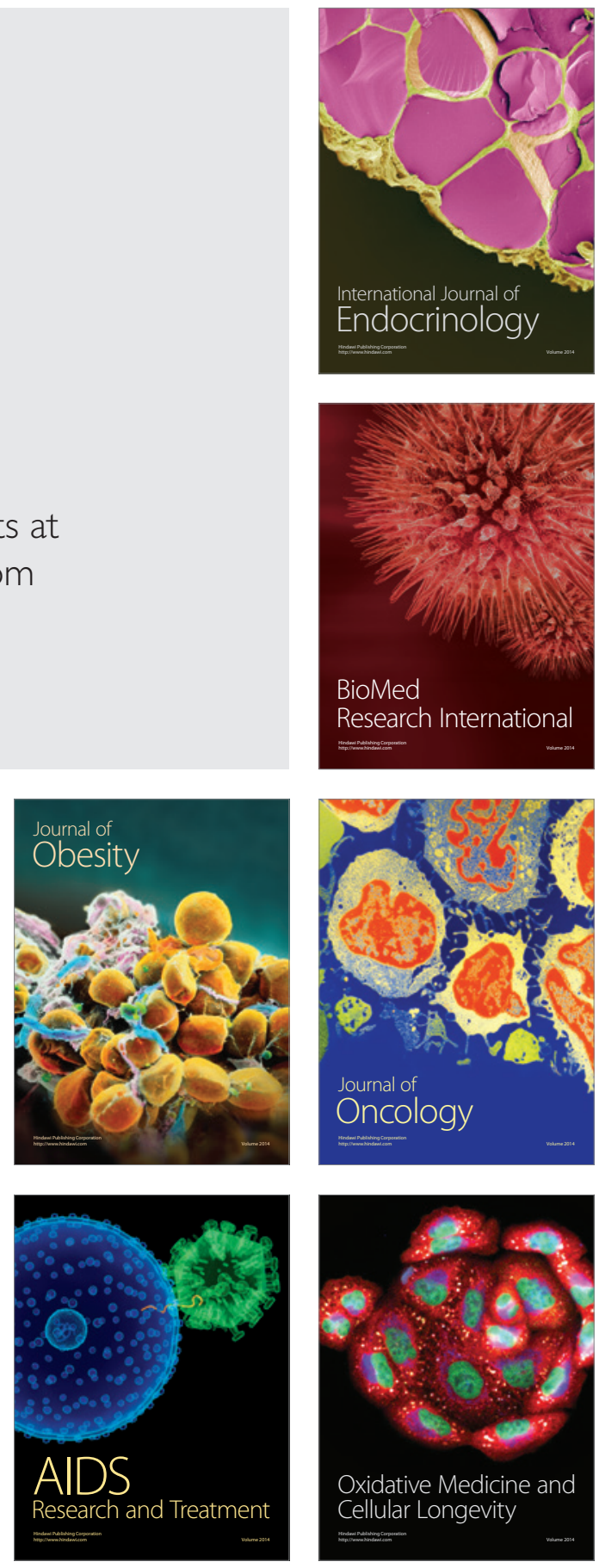